\title{
Effects of land use and seasonality on stream water quality in a small tropical catchment: The headwater of Córrego Água Limpa, São Paulo (Brazil)
}

\author{
Valdemir Rodrigues ${ }^{a}$, Joan Estrany ${ }^{b}$, Mauricio Ranzini ${ }^{c}$, Valdir de Cicco ${ }^{c}$, José Ma ${ }^{a}$. Tarjuelo Martín-Benito ${ }^{\mathrm{d}}$, \\ Javier Hedo ${ }^{\mathrm{d}}$, Manuel E. Lucas-Borja ${ }^{\mathrm{d}, *}$ \\ a Universidade Estadual Paulista, Faculdade de Ciências Agronômicas, Departamento de Solos e Recursos Ambientais, Caixa Postal: 1780, 18610-307 Botucatu, SP, Brazil

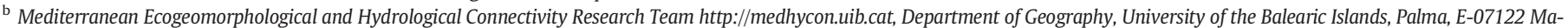 \\ llorca, Balearic Islands, Spain \\ c Instituto Florestal de São Paulo, Brazil \\ d Universidad de Castilla-La Mancha, Campus Universitario s/n, C.P. 02071 Albacete, Spain
}

\section{H I G H L I G H T S}

- The study enhances significant relationships among land use and water quality.

- Results showed temporal differences in the linkage between agricultural use and water quality.

- Water quality parameters were influenced by temporal and spatial differences.

- Water quality parameters correlations were influenced by seasonality.

- Princiapal Component analysis clustered both rainy and dry periods and the distances from the natural water source.

\section{A R T I C L E I N F O}

\section{Article history:}

Received 18 August 2017

Received in revised form 4 October 2017

Accepted 4 October 2017

Available online 18 October 2017

Editor: D. Barcelo

\section{Keywords:}

Water quality

Land use

Seasonal variation

Dry and rainy period

Tropical area

\section{G R A P H I C A L A B S T R A C T}

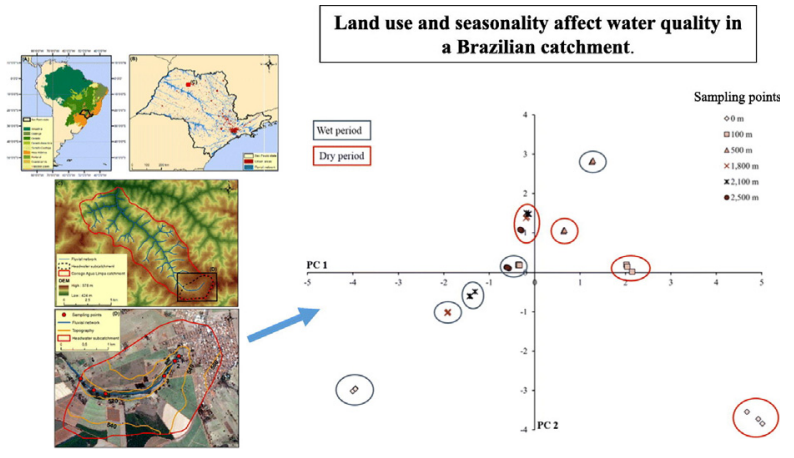

\section{A B S T R A C T}

Stream water quality is controlled by the interaction of natural and anthropogenic factors over a range of temporal and spatial scales. Among these anthropogenic factors, land cover changes at catchment scale can affect stream water quality. This work aims to evaluate the influence of land use and seasonality on stream water quality in a representative tropical headwater catchment named as Córrego Água Limpa (Sao Paulo, Brasil), which is highly influenced by intensive agricultural activities and urban areas. Two systematic sampling approach campaigns were implemented with six sampling points along the stream of the headwater catchment to evaluate water quality during the rainy and dry seasons. Three replicates were collected at each sampling point in 2011. Electrical conductivity, nitrates, nitrites, sodium superoxide, Chemical Oxygen Demand (DQO), colour, turbidity, suspended solids, soluble solids and total solids were measured. Water quality parameters differed among sampling points, being lower at the headwater sampling point ( $0 \mathrm{~m}$ above sea level), and then progressively higher until the last downstream sampling point ( $2500 \mathrm{~m}$ above sea level). For the dry season, the mean discharge was $39.5 \mathrm{~s}^{-1}$ (from April to September) whereas $113.0 \mathrm{~s}^{-1}$ were averaged during the rainy season (from October to March). In addition, significant temporal and spatial differences were observed $(P<0.05)$ for the fourteen parameters during the rainy and dry period. The study enhance significant relationships among land use and water quality and its temporal effect, showing seasonal differences between the land use and water quality connection,

\footnotetext{
* Corresponding author.

E-mail address: ManuelEsteban.Lucas@uclm.es (M.E. Lucas-Borja).
} 
highlighting the importance of multiple spatial and temporal scales for understanding the impacts of human activities on catchment ecosystem services.

\section{Introduction}

The stream water quality is controlled by the interaction of natural (i.e. rainfall intensity, frequency and amount, river discharge, geology and soil type, topography and vegetation cover) and anthropogenic (i.e. abstraction, urbanization or impounding; discharges from industry, agriculture or sewerage) factors over a range of temporal and spatial scales. Many of these anthropogenic influences are part of land cover change at catchment scale that can affect stream water quality (Baker, 2003). As Keesstra (2007) stated, the abandonment of agricultural fields followed by natural reforestation changed the water quality and sediment supply to the streams in south-western Slovenia. Changes in species composition may also alter sediment concentration and runoff water quality (Cerdà et al., 2017) Moreover, urban wastewater discharge may constitute a constant and important polluting source, whereas diffuse source inputs are associated with agricultural areas (Carter et al., 2003). On this context, many different papers have deal with modelling, sediment redistribution and water quality at catchment-scale in Continental and Mediterranean environments (Keesstra, 2007; Keesstra et al., 2014; Van Eck et al., 2016). However, studies applying hydrological models to tropical catchments are scarce and it is necessary to evaluate water quality changes under different land uses. In fact, modelling water quality response of a tropical catchment can constitute a challenge because hydrological processes in these areas are difficult to assess (Pérez Hernández and López, 1998; Hartemink et al., 2008).

Surface runoff is a seasonal phenomenon, largely affected by land use and climate within the basin (Singh et al., 2004). Tropical catchments are precisely characterized by strong seasonality of climate with pronounced wet and dry seasons in which precipitation is determined by the oscillation of the intertropical convergence zone (Pérez Hernández and López, 1998). In addition, the impact of land use change on stream water quality dynamics is particularly severe in tropical areas due to a more rapid mineralization of tropical soil organic matter and often, high erosionthan in temperate zones (Grip et al., 2004; Hartemink et al., 2008). This land use change has been dramatic since rural landscapes have been deeply affected mainly through deforestation from agriculture and pasture (Allan, 2004). For instance, in São Paulo state, SE Brazil, only about $13 \%$ of the original forest persists, mainly in the form of fragments (Ribeiro Rodrigues and Lúcia Ramos Bononi, 2008), including here remnants of riparian forests. Accordingly, vegetation of riparian zones has a demonstrated buffer capacity for avoiding the transfer of diffuse contaminants to surface waters (Connolly et al., 2015). As different studies have demonstrated, landscape connectivity may be altered after land use changes (i.e. from forest to agricultural land uses) increasing sediment connectivity and thus, changing water quality along streams (Parsons et al., 2015; R.J. Masselink et al., 2017, R. Masselink et al., 2017).

Land use-water quality relationships allow, using land use, to estimate and understand water quality in rivers suffering from diffuse pollution (Lee et al., 2009). Thereby, knowledge in such relationships at a catchment scale across seasons is still lacking due to the large area and monitoring difficulties. Identifying the spatial and seasonal variability of land use impacts on water quality represents a significant challenge for understanding the land use impacts on water quality. Investigation of the relationship between land cover and water quality is particularly useful when considering diffuse source pollution in agricultural and urban areas (Narany et al., 2017). However, in running waters, where changes in hydrology are rapid and difficult to estimate, they cannot reflect the integration of numerous environment factors and long-term sustainability of river ecosystems for their instantaneous nature.

Understanding the relationship between land use and surface water quality is necessary for effective water management and for identifying primary threats to water quality, and the relationships are meaningful for effective water quality management. Land use, season and surface water quality can be used to target critical land use areas and to institute relevant measures to minimize pollutant loadings. The aim of this work is to evaluate the influence of land use and seasonality on stream water quality in a small tropical catchment during both rainy and dry seasons of 2011. We hypothesized that there is an impact of land use on water quality in the Córrego Água Limpa, São Paulo and that (2) there are seasonal differences in the impacts of land use on water quality.

\section{Materials and methods description}

\subsection{Study area description}

This study was carried out in the headwater parts of the Córrego Água Limpa, a representative tropical catchment modified by intensive and commercial agricultural systems and urban areas. The Córrego Água Limpa catchment (from $20^{\circ} 45^{\prime} 15^{\prime \prime} \mathrm{S}$ to $20^{\circ} 51^{\prime} 48^{\prime \prime} \mathrm{S}$; from $49^{\circ} 37^{\prime}$ $48^{\prime \prime} \mathrm{W}$ to $49^{\circ} 45^{\prime} 21^{\prime \prime} \mathrm{W}$ ) is located between Neves Paulista and Monte Aprazível counties, São Paulo State, Brazil (Fig. 1). The catchment has an area of $64.2 \mathrm{~km}^{2}$ and a perimeter of $39.7 \mathrm{~km}$. The average altitude is $500 \mathrm{~m}$ and the average gradient slope $5.4 \%$. From the geologic point of view, materials from the Upper Cretaceous characterize the study area with fluvial deposits in which sandy elements predominate. In addition, carbonic and sandy-clay elements can be found in the Upper Cretaceous layers (Rodrigues and Carvalho, 2009). The drainage density is $1.10 \mathrm{~km}$ of river length by $\mathrm{km}^{2}$ of catchment area. This low value is derived by the permeability of soils and parent material, resulting in high runoff coefficients ( $>20 \%$ ). The form factor is 0.31 , which is considered low and prolonged shaped. Upper Cretaceous rocks occur in the study area. Fluvial deposits compose the soil found at the study area with predominance of fine and very fine sandstones and carbonate nodules. In addition, massive banks of sandy and clayey silts are found.

The climate can be classified as Aw; i.e., tropical with a rainy period in summer and dry period in winter according to Köppen climatic classification (Rodrigues and Carvalho, 2009). During the period 19602010 , the mean annual temperature was $23.5^{\circ} \mathrm{C}$ (the mean lowest temperature of the coldest month was $11.8^{\circ} \mathrm{C}$ and the mean highest temperature of the hottest month $30.9{ }^{\circ} \mathrm{C}$ ) and the mean annual precipitation $1355 \mathrm{~mm}$ (42 $\mathrm{mm}$ in the dry period and $441 \mathrm{~mm}$ in the rainy period). The meteorological dynamics for the study period (2011) and the climatic characteristics for the last 40 years can be observed in Fig. 2. The flow regime is intermittent with flow normally being higher from September to April. The mean daily discharge during the study period 2011 was ca. $22.21 \mathrm{~s} \mathrm{~s}^{-1}$.

This study was conducted in the headwater part of Córrego Agua Limpa catchment, encompassing $5.6 \mathrm{~km}^{2}$. The elevation is from 497 to $560 \mathrm{~m}$ following the spatial distribution showed in the digital elevation model (Fig. 1). The forestland use, mainly composed by native vegetation such as Astronium urundeuva (Fr.All.) Engl, Hibiscus pernambucensis Arruda, Tabebuia avellanedae Lorentz ex Griseb, Chorisia speciosa St.-Hill. and Genipa americana L. and pasture (mainly Brachiaria decumbens Stapf) dominates the landscape with 37.4\%. Agriculture (37.0\%) with rubber trees (Hevea brasiliensis Muell. Arg) and sugarcane (Saccharum 

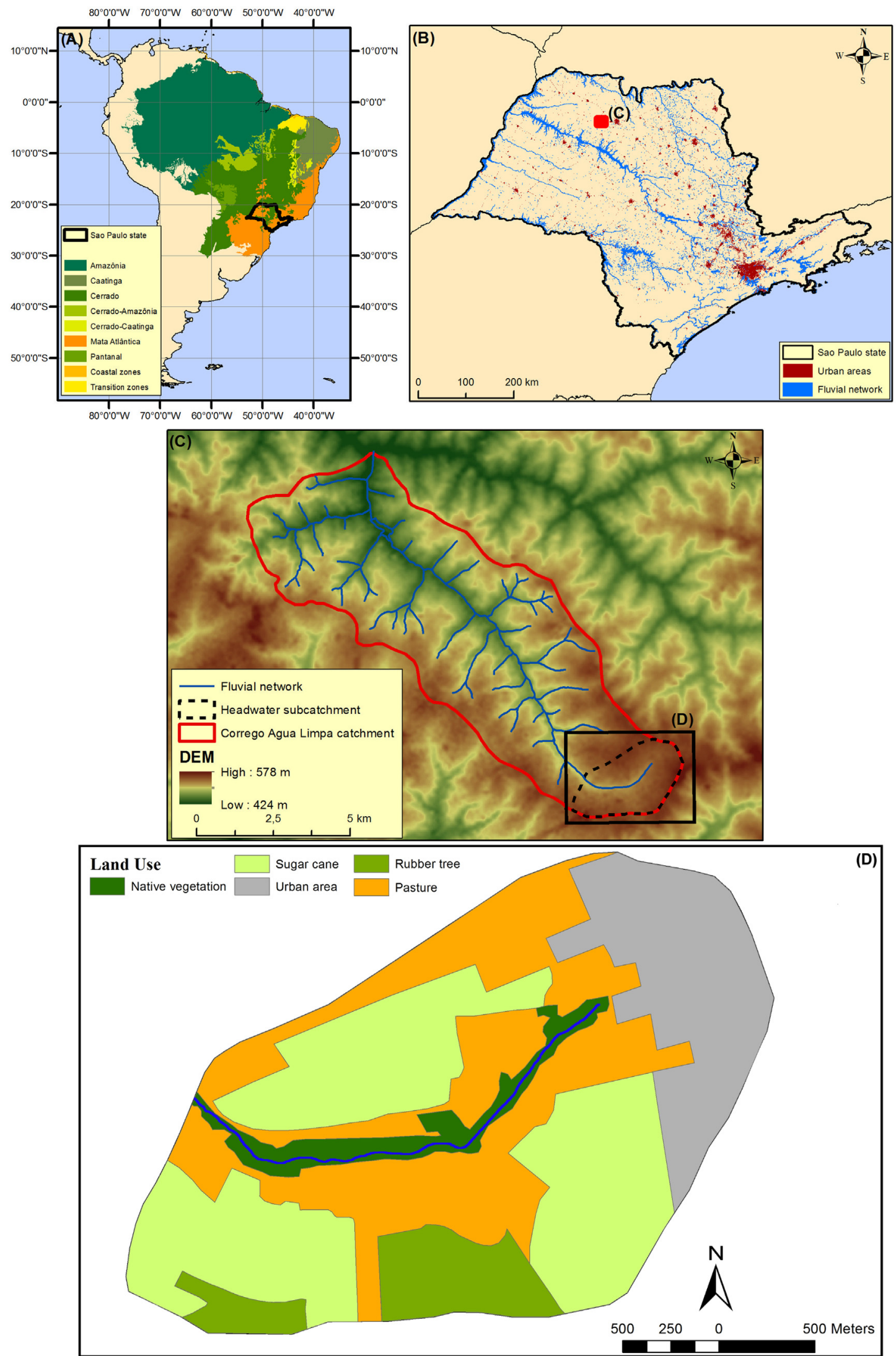

Fig. 1. Study area.

officinarum L.) is also mainly present in the headwater catchment (Fig. 1). Additionally, an urban area (17.3\%; Neves Paulista) is located in the headwater catchment, conditioning the hydrological response.
The native vegetation is mainly restricted to riparian zones whereas the agricultural land use and pastures are randomly distributed along the headwater catchment. No forest management is applied to the 


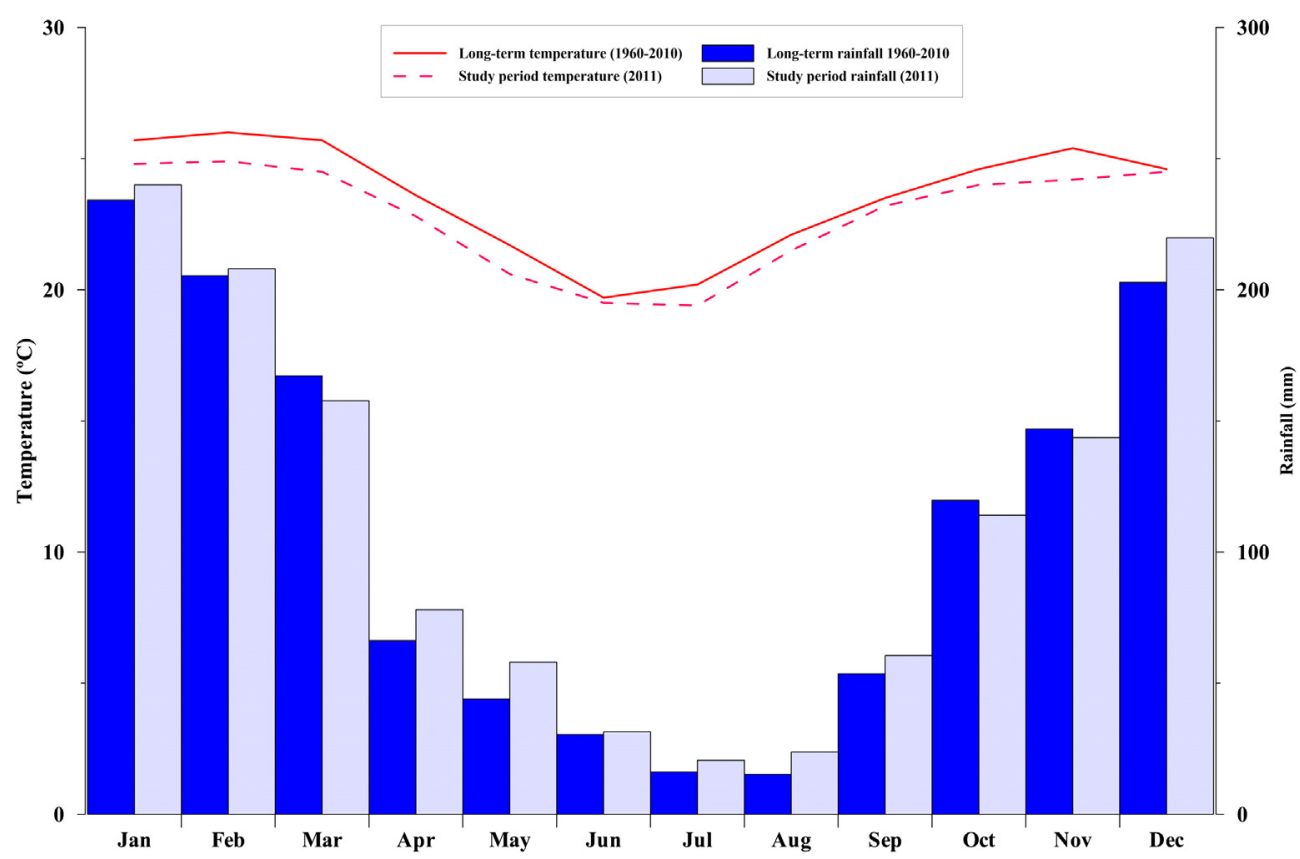

Fig. 2. Climatic records for the study area.

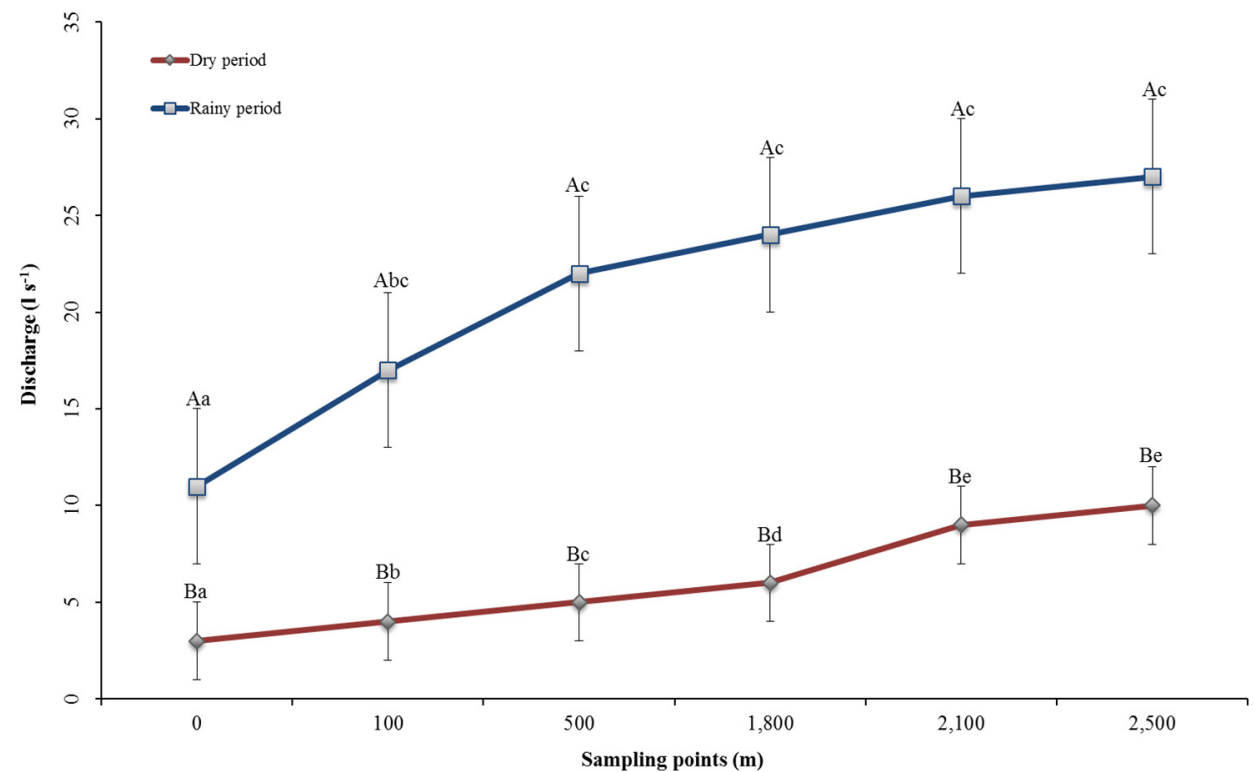

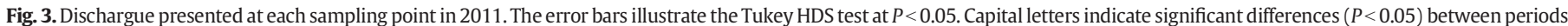
and lowercase indicate significant differences $(P<0.05)$ comparing sampling points at each period.

native vegetation, which naturally growths without anthropic influences. Pasture is managed under an extensive livestock production system whereas. In their turn, rubber tree and sugar cane crops areas are managed under intensive productions systems (Rodrigues et al., 2015). These same authors noted that this headwater catchment currently presents land use conflicts in about $65.2 \%$ of the total area and

Table 1

Result of the two-factor analysis of variance for the physicochemical analysis ${ }^{\mathrm{a}}$.

\begin{tabular}{|c|c|c|c|c|c|c|c|c|c|c|c|c|}
\hline & \multicolumn{2}{|l|}{$\mathrm{pH}$} & \multicolumn{2}{|l|}{ EC } & \multicolumn{2}{|l|}{ COD } & \multicolumn{2}{|l|}{ Colour } & \multicolumn{2}{|c|}{ Turbidity } & \multicolumn{2}{|l|}{ Total Fe } \\
\hline & F ratio & $P$-value & F ratio & $P$-value & F ratio & $P$-value & F ratio & $P$-value & F ratio & $P$-value & F ratio & $P$-value \\
\hline A: Period of the year & 20.50 & 0.001 & 920.25 & 0.001 & 164.78 & 0.001 & 538.17 & 0.001 & 316.46 & 0.001 & 108.60 & 0.001 \\
\hline B: Sampling point & 27.41 & 0.001 & 231.58 & 0.001 & 309.85 & 0.001 & 140.37 & 0.001 & 324.92 & 0.001 & 127.48 & 0.001 \\
\hline $\mathrm{AxB}$ & 196.47 & 0.001 & 295.57 & 0.001 & 703.80 & 0.001 & 521.01 & 0.001 & 808.94 & 0.001 & 753.28 & 0.001 \\
\hline
\end{tabular}

${ }^{a}$ EC $\left(\mu \mathrm{Sm}^{-1}\right)$, Electrical Conductivity; COD $\left(\mathrm{mg} \mathrm{l}^{-1}\right)$, Chemical Oxygen Demand; Colour (UHT); Turbidity (NTU); Total Fe (mg $\mathrm{l}^{-1}$ ). 
Table 2

Result of the two-factor analysis of variance for the physicochemical analysis ${ }^{\mathrm{a}}$.

\begin{tabular}{|c|c|c|c|c|c|c|c|c|c|c|}
\hline & \multicolumn{2}{|l|}{$\mathrm{NO}_{3}^{-} \mathrm{N}$} & \multicolumn{2}{|l|}{$\mathrm{NO}_{3}^{-}$} & \multicolumn{2}{|l|}{$\mathrm{NO}_{2}^{-} \mathrm{N}$} & \multicolumn{2}{|l|}{$\mathrm{NaNO}_{2}$} & \multicolumn{2}{|l|}{$\mathrm{NO}_{2}^{-}$} \\
\hline & F ratio & $P$-value & F ratio & $P$-value & F ratio & $P$-value & F ratio & $P$-value & F ratio & $P$-value \\
\hline A: Period of the year & 248.00 & 0.001 & 109.34 & 0.001 & 279.00 & 0.001 & 655.61 & 0.001 & 548.65 & 0.001 \\
\hline B: Sampling point & 229.00 & 0.001 & 142.33 & 0.001 & 192.20 & 0.001 & 491.99 & 0.001 & 470.99 & 0.001 \\
\hline $\mathrm{AxB}$ & 139.00 & 0.001 & 825.96 & 0.001 & 119.20 & 0.001 & 542.03 & 0.001 & 456.99 & 0.001 \\
\hline
\end{tabular}

${ }^{\text {a }} \mathrm{NO}_{3}-\mathrm{N}\left(\mathrm{mg} \mathrm{l}^{-1}\right)$, Nitrate; $\mathrm{NO}_{3-}\left(\mathrm{mg} \mathrm{l}^{-1}\right)$, Nitrate; $\mathrm{NO}_{2}-\mathrm{N}\left(\mathrm{mg} \mathrm{l}^{-1}\right)$, Nitrite; $\mathrm{NaNO}_{2}\left(\mathrm{mg} \mathrm{l}^{-1}\right)$, Sodium $\mathrm{Nitrite} \mathrm{NO}_{2-}$, Sodium Superoxide.

pasture and intensive land use management should be replaced by native vegetation in order to reach a more sustainable land uses development (Rodrigues et al., 2015).

\subsection{Sampling sites and water quality}

A systematic sampling approach was implemented with six sampling points along the stream of the headwater catchment to evaluate water quality during the tropical rainy and dry seasons. The first sampling point was set up on a natural water spring which release effluent to the main stream at the headwater of the catchment (i.e., $0 \mathrm{~m}$ above sea level). The rest of sampling points were established at 100,500 , 1800,2100 and $2500 \mathrm{~m}$ above sea level downstream from the natural water spring (Fig. 1). Two sampling campaigns were carried out. The first one in December 2011, during the rainy season; whilst the second one was developed in July 2011, during the dry season. At each sampling point, three replicas were collected during the campaigns both in dry and rainy seasons in 2011. The total samples were 36: 6 sampling points $\times 2$ periods $\times 3$ replicas. Electrical conductivity (EC), nitrate $\left(\mathrm{NO}_{3}-\mathrm{N}\right)$, nitrate $\left(\mathrm{NO}_{3}-\right)$, nitrite $\left(\mathrm{NO}_{2}-\mathrm{N}\right)$, sodium nitrite $\left(\mathrm{NaNO}_{2}\right)$, sodium superoxide $\left(\mathrm{NO}_{2}-\right)$, DQO, colour, turbidity, suspended solids, soluble solids and total solids were measured, considering that the last three parameters were only measured during the rainy period. The values of $\mathrm{pH}$ and $\mathrm{EC}$ were directly measured in situ using a multiparameter water quality-monitoring instrument YSI 85. The rest of the parameters were measured in the laboratory according to the National standard criterion (GB 3838-2002). This national criterion was formulated for the purpose of implementing the Environmental Protection Law of the People's Republic of China and the Law of the People's Republic of China on Prevention and Control of Water Pollution, preventing water pollution, protecting surface water quality and human health as well as maintaining sound eco-system. Finally, stream flow discharge $\left(1 \mathrm{~s}^{-1}\right)$ was measured three times at each sampling point in both dry and rainy seasons in 2011 using a portable flow meter model PTFM 1.0. The stream flow discharge measurements were carried out at the same time of the sampling campaigns.

\subsection{Statistical analysis}

For water quality properties and stream flow dynamics, the data were submitted to two-way ANOVA in which sampling point and period of the year were selected as the factors. To satisfy the assumptions of the statistical test-equality of variance and normal distribution-, variables were square root transformed when necessary. The post-hoc test applied was the Tukey HSD test. A significance level of $P<0.05$ was adopted throughout, unless otherwise stated. Correlation analyses were performed using Pearson's method (Rodgers and Nicewander, 1988) using also a significance level of $P<0.05$. A multivariate statistical method using the principal component analysis (PCA) and the correlation matrix was carried out to study the structure of dependence and correlation among the variables in the six sampling points during the study period. The software used for the statistical analysis was Statgraphics Plus 6.0®.

\section{Results}

\subsection{Hydrometeorological conditions during 2011}

\subsubsection{Rainfall and discharge}

Rainfall values registered during 2011 were similar to 1960-2010 period. During the dry season, $272.2 \mathrm{~mm}$ were recorded (from April to September; 45.4 by month in average). For the rainy season (from October to March), $1081.1 \mathrm{~mm}$ were recorded (180.5 by month in average).

Differences among sampling points were also observed in relation to discharge. The mean annual discharge was ca. $14.41 \mathrm{~s}^{-1} 1 \mathrm{~s}^{-1}$ (Fig. 3). For the dry season, the mean discharge was $39.5 \mathrm{l} \mathrm{s}^{-1}$ (from April to September; $6.61 \mathrm{~s}^{-1}$ by month in average) whereas $113.01 \mathrm{~s}^{-1}$ were averaged recorded during the rainy season ((from October to March; $22.21 \mathrm{~s}^{-1}$ by month in average). In addition, a clear downstream increase trend in the discharge was observed for the study period (Fig. 3). The discharge was higher during the rainy season in the downstream sampling points (from 500 to $2500 \mathrm{~m}$ from the natural water spring) and lower in the headwater sampling points (between 0 and $100 \mathrm{~m}$ from the natural water spring) (Fig. 3). The same trend was found in the dry period and higher discharge values were found in the most upper stream sampling point $\left(2.1 \mathrm{l} \mathrm{s}^{-1}\right.$ at the natural water spring) comparing to the downstream sampling points (27.0 and $28.0 \mathrm{~s}^{-1}$ at the 2100 and 2500 sampling points, respectively).

\subsection{Water quality parameters in the headwater parts of Córrego Água Lim- pa catchment}

Differences among sampling points were also observed, being lower at the headwater sampling point ( $0 \mathrm{~m}$ above sea level), and then progressively higher until the last downstream sampling point $(2500 \mathrm{~m}$ above sea level). Significant temporal and spatial differences were observed in the ANOVA test $(P<0.05)$ for the fourteen parameters during the rainy and dry period. As shown in Tables 1 and 2, the interaction between seasonality and the location of each sampling point was always statistically significant for the parameters. Similarly, suspended solids, soluble solids and total solids were significantly influenced $(P<0.05)$ by the location factor of each sampling point (Table 3). Figs. 4-6 illustrate the mean concentrations of the parameters in both rainy and dry periods for each sampling point (Tukey HDS post-hoc analyses at $P<$ 0.05 ). Mean $\mathrm{pH}$ values varied from 7.2 at the beginning of the longitudinal section to 5.9 at the end in the rainy period. During the dry period, the mean $\mathrm{pH}$ values varied from 5.8 to 6.6 respectively (Fig. 4 ). The EC was higher during the rainy period in the headwater sampling points ( 0 and $500 \mathrm{~m}$ above sea level from the natural water spring) and lower in the downstream sampling points (between 1800 and $2500 \mathrm{~m}$

Table 3

Result of the one-factor analysis of variance for the suspended solids, soluble solids and total solids during the rainy season ${ }^{\mathrm{a}}$.

\begin{tabular}{|c|c|c|c|c|c|c|}
\hline & \multicolumn{2}{|c|}{ Suspended solids } & \multicolumn{2}{|c|}{ Soluble solids } & \multicolumn{2}{|c|}{ Total solids } \\
\hline & F ratio & $P$-value & F ratio & $P$-value & F ratio & $P$-value \\
\hline Sampling point & 245.12 & 0.001 & 514.02 & 0.001 & 274.25 & 0.001 \\
\hline
\end{tabular}



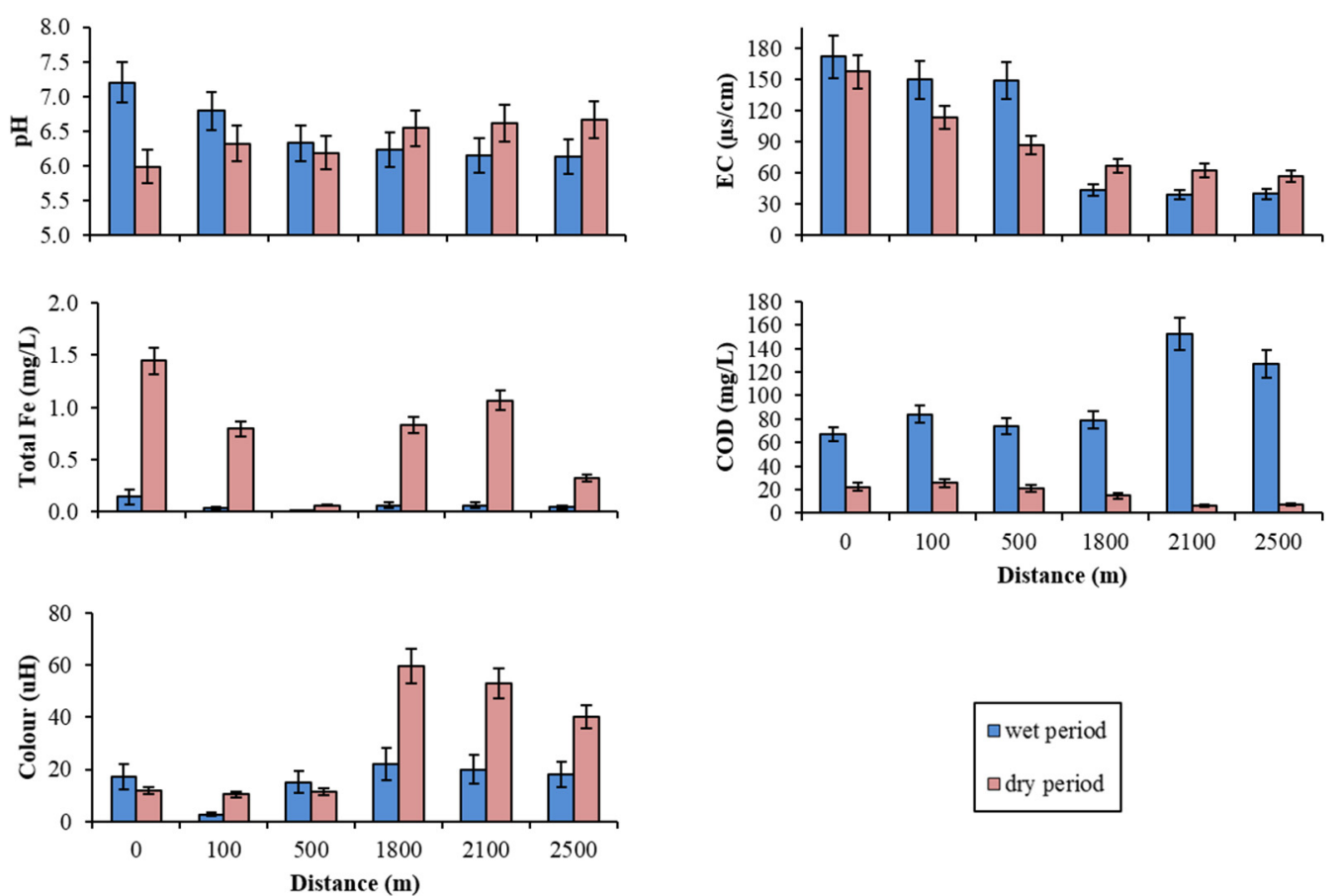

$\square$ wet period
$\square$ dry period

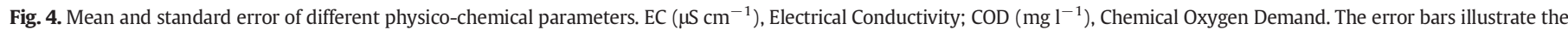
Tukey HDS test at $P<0.05$.

above sea level from the natural water spring) (Fig. 4). The same trend was found in the dry period and higher EC values were found in the headwater sampling points comparing to the downstream sampling points. The chemical demand of oxygen (CDO) was significantly higher during the rainy period whereas colour and total Fe parameters were higher during the dry period, being the differences among sampling points weak for the three parameters. Differences comparing turbidity in both rainy and dry periods were also small, finding a higher value at the downstream sampling points (Fig. 4). $\mathrm{NO}_{3}-\mathrm{N}$ and $\mathrm{NO}_{3}-$ did significantly varied during the two sampling periods and also along the longitudinal section; excepting the $500 \mathrm{~m}$ above sea level sampling point during the dry period when the highest value of both parameters was observed (Fig. 5). In relation to $\mathrm{NO}_{2}-\mathrm{N}, \mathrm{NaNO}_{2}$ and $\mathrm{NO}_{2}-$, higher values were found at the headwater natural water spring during the rainy
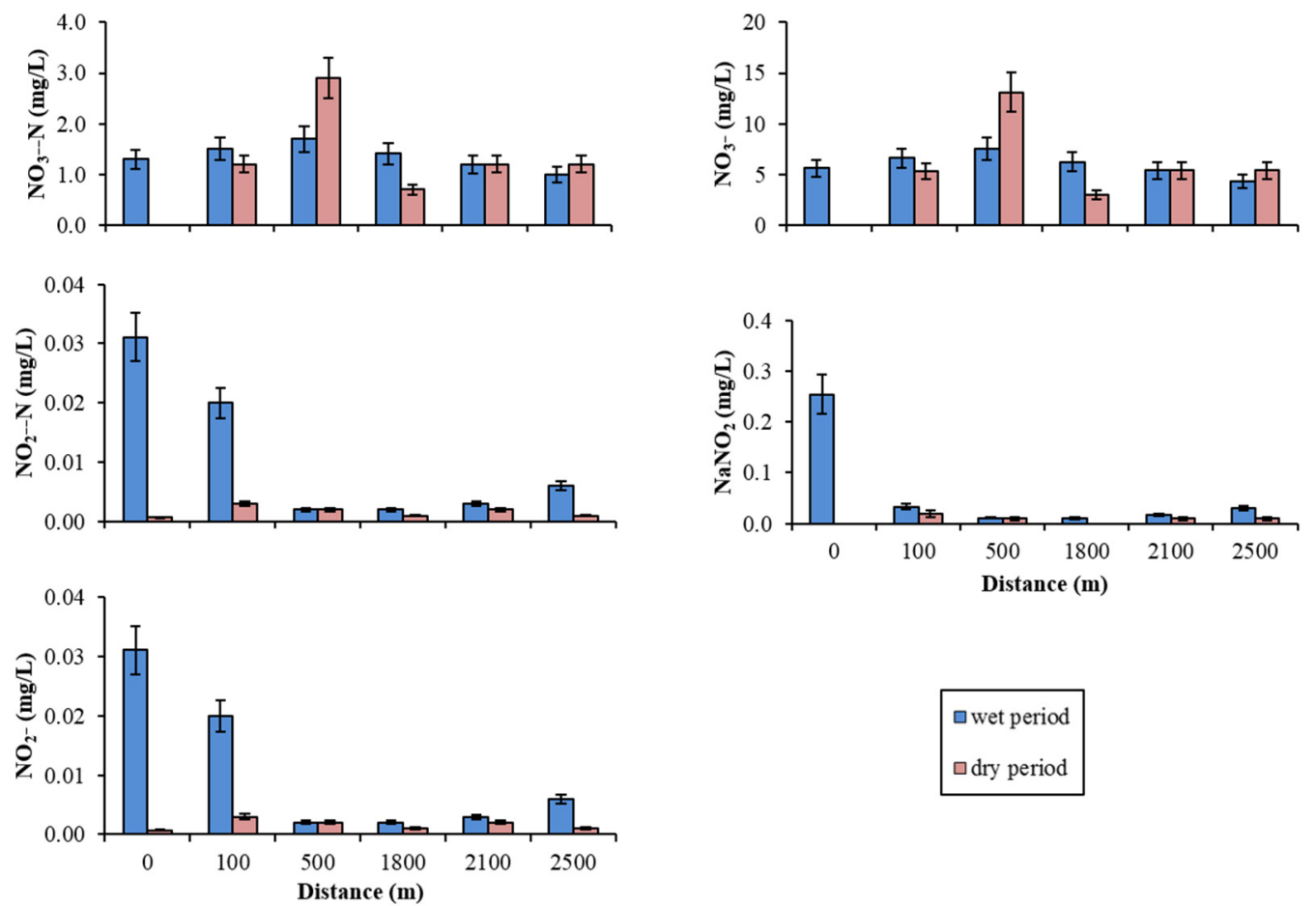

$$
\begin{aligned}
& \square \text { wet period } \\
& \square \text { dry period }
\end{aligned}
$$

Fig. 5. Mean and standard error of different physic-chemical parameters. The error bars illustrate the Tukey HDS test at $P<0.05$. 

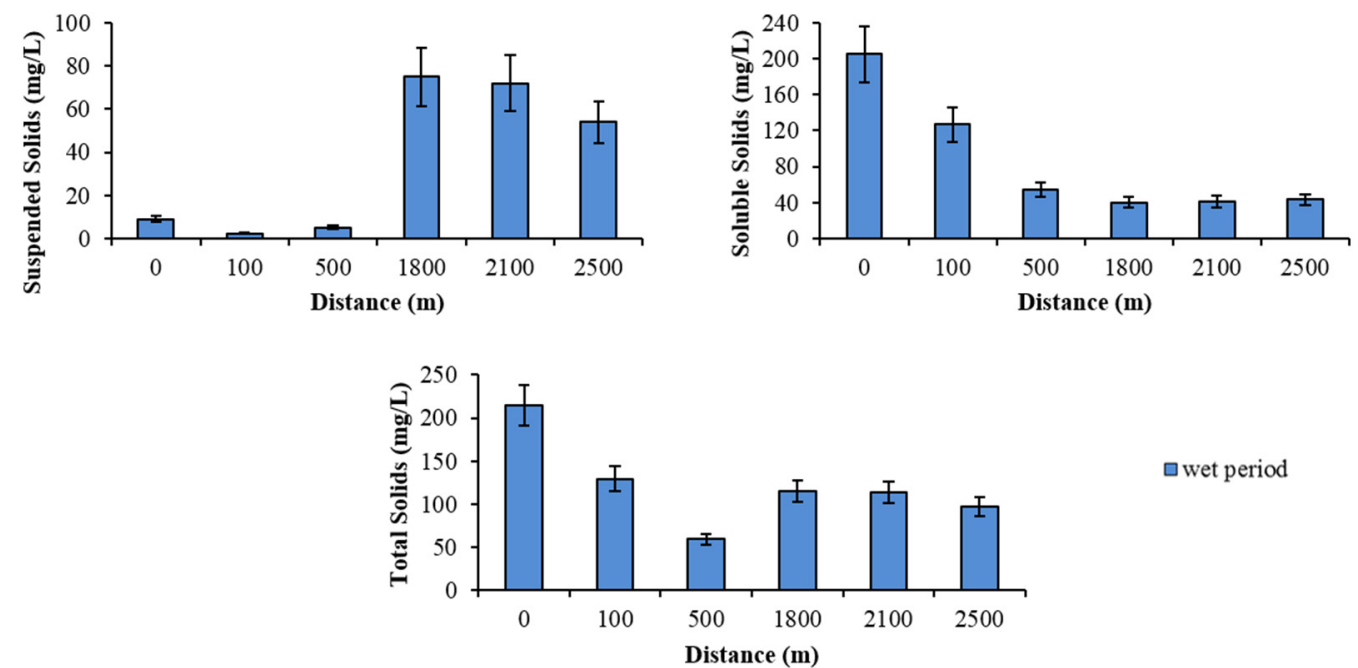

Fig. 6. Mean and standard error of different physic-chemical parameters for the rainy period only. The error bars illustrate the Tukey HDS test at $P<0.05$.

period (Fig. 5). Suspended solids were higher at the downstream sampling points; i.e., 1800 and $2500 \mathrm{~m}$ above sea level sampling points (Fig. 6). Conversely, soluble solids and total solids showed an opposite trend.

\subsection{Relationship between water quality parameters}

Positive and significant correlation coefficients were found between $\mathrm{pH}$ and $\mathrm{EC}, \mathrm{NO}_{2}-\mathrm{N}, \mathrm{NaNO}_{2}$ and $\mathrm{NO}_{2}^{-}$(Table $4 \mathrm{~A}$ and $\mathrm{B}$ ). However, water quality parameters correlations were influenced by seasonality and correlation factors differed comparing the dry and wet season (Table 4A and $\mathrm{B}$ ). Turbidity and $\mathrm{pH}$ were negative and significantly correlated in both wet and dry seasons. EC was positively correlated with $\mathrm{NO}_{2}-\mathrm{N}$, $\mathrm{NaNO}_{2}$ and $\mathrm{NO}_{2}^{-}$in the wet season whereas results showed a contrary trend during the dry season. $\mathrm{NO}_{3}-\mathrm{N}^{2}$ and $\mathrm{NO}_{3}^{-}$were always negative and significant correlated with colour, turbidity and total Fe in both wet and dry seasons. Also, DQO was positive and significantly correlated with turbidity and negatively correlated with $\mathrm{pH}$. EC and DQO correlation parameters were affected by seasonality. The rest of correlation coefficients can be observed in Table 4A and B.

\subsection{Relationship between seasonality, stream length and water quality parameters}

The multivariate PCA analysis showed differences comparing sampling point and period of the year factors, clearly clustering both rainy and dry periods and the distances from the natural water source (Fig. 7). The PC1 explained $40.5 \%$ of variability and PC2 explained $29.8 \%$ of the variability ( $70.7 \%$ of variability explained by the two components). $\mathrm{NO}_{2}-\mathrm{N}, \mathrm{NaNO}_{2}$ and $\mathrm{NO}_{2}-$ had a positive weight on $\mathrm{PC} 1$ whereas colour, turbidity and total Fe had a negative weight on PC 1 (Table 5). EC, $\mathrm{NaNO}_{2}, \mathrm{NO}_{2}-$ (negative weight), $\mathrm{NO}_{3}-\mathrm{N}, \mathrm{NO}_{3}-$ (positive weight) were the most important parameters in the PC2. The others loading factors of the different variables appear in Table 5.

Table 4

Correlation matrix for the parameters used in this study on the a) wet and b) dry season.

\begin{tabular}{|c|c|c|c|c|c|c|c|c|c|c|}
\hline A & $\mathrm{pH}$ & EC & $\mathrm{NO}_{3}-\mathrm{N}$ & $\mathrm{NO}_{3-}$ & $\mathrm{NO}_{2}-\mathrm{N}$ & $\mathrm{NaNO}_{2}$ & $\mathrm{NO}_{2-}^{-}$ & DQO & Colour & Turbidity \\
\hline EC & $0.82^{a}$ & & & & & & & & & \\
\hline $\mathrm{NO}_{3}-\mathrm{N}$ & $0.21 \mathrm{~ns}$ & $0.61^{a}$ & & & & & & & & \\
\hline $\mathrm{NO}_{3-}^{-}$ & $0.16 \mathrm{~ns}$ & $0.56^{\mathrm{a}}$ & $0.99^{\mathrm{a}}$ & & & & & & & \\
\hline $\mathrm{NO}_{2}-\mathrm{N}$ & $0.97^{a}$ & $0.73^{\mathrm{a}}$ & $0.03 \mathrm{~ns}$ & $-0.02 \mathrm{~ns}$ & & & & & & \\
\hline $\mathrm{NaNO}_{2}$ & $0.83^{\mathrm{a}}$ & $0.57^{\mathrm{a}}$ & $-0.12 \mathrm{~ns}$ & $-0.17 \mathrm{~ns}$ & $0.88^{\mathrm{a}}$ & & & & & \\
\hline $\mathrm{NO}_{2^{-}}$ & $0.83^{\mathrm{a}}$ & $0.57^{a}$ & $-0.12 \mathrm{~ns}$ & $-0,17 \mathrm{~ns}$ & $0.88^{a}$ & $0.99^{\mathrm{a}}$ & & & & \\
\hline DQO & $-0.62^{\mathrm{a}}$ & $-0.74^{\mathrm{a}}$ & $-0.68^{\mathrm{a}}$ & $-0,63^{a}$ & $-0.50^{\mathrm{a}}$ & $-0.42^{\mathrm{a}}$ & $-0.43^{a}$ & & & \\
\hline Colour & $-0.44^{\mathrm{a}}$ & $-0.60^{\mathrm{a}}$ & $-0.40^{\mathrm{a}}$ & $-0.38^{\mathrm{a}}$ & $-0.38^{\mathrm{a}}$ & $0.07 \mathrm{~ns}$ & $0.07 \mathrm{~ns}$ & $0.28 \mathrm{~ns}$ & & \\
\hline Turbidity & $-0.83^{a}$ & $-0.78^{\mathrm{a}}$ & $-0.44^{a}$ & $-0.41^{a}$ & $-0.78^{\mathrm{a}}$ & $-0.42^{a}$ & $-0.42^{a}$ & $0.57^{\mathrm{a}}$ & $0.79^{\mathrm{a}}$ & \\
\hline Total Fe & $-0.64^{a}$ & $0.21 \mathrm{~ns}$ & $-0.35^{a}$ & $-0.37^{\mathrm{a}}$ & $0.73^{\mathrm{a}}$ & $0.90^{\mathrm{a}}$ & $0.90^{\mathrm{a}}$ & $-0.19 \mathrm{~ns}$ & $0.32^{\mathrm{a}}$ & $-0.25 \mathrm{~ns}$ \\
\hline B & $\mathrm{pH}$ & EC & $\mathrm{NO}_{3}-\mathrm{N}$ & $\mathrm{NO}_{3}-$ & $\mathrm{NO}_{2}-\mathrm{N}$ & $\mathrm{NaNO}_{2}$ & $\mathrm{NO}_{2-}$ & DQO & Colour & Turbidity \\
\hline EC & $-0.91^{\mathrm{a}}$ & & & & & & & & & \\
\hline $\mathrm{NO}_{3}-\mathrm{N}$ & $0.05 \mathrm{~ns}$ & $-0.40^{\mathrm{a}}$ & & & & & & & & \\
\hline $\mathrm{NO}_{3^{-}}$ & $0.05 \mathrm{~ns}$ & $-0.40^{\mathrm{a}}$ & $0.99^{\mathrm{a}}$ & & & & & & & \\
\hline $\mathrm{NO}_{2}-\mathrm{N}$ & $0.03 \mathrm{~ns}$ & $-0.05 \mathrm{~ns}$ & $0.49^{a}$ & $0,48^{\mathrm{a}}$ & & & & & & \\
\hline $\mathrm{NaNO}_{2}$ & $0.08 \mathrm{~ns}$ & $-0.13 \mathrm{~ns}$ & $0.61^{\mathrm{a}}$ & $0.61^{\mathrm{a}}$ & $0.95^{\mathrm{a}}$ & & & & & \\
\hline $\mathrm{NO}_{2-}$ & $0.35^{a}$ & $-0.43^{\mathrm{a}}$ & $0.69^{\mathrm{a}}$ & $0.69^{a}$ & $0.67^{a}$ & $0.82^{\mathrm{a}}$ & & & & \\
\hline DQO & $-0.82^{\mathrm{a}}$ & $0.78^{\mathrm{a}}$ & $0.04 \mathrm{~ns}$ & $0.04 \mathrm{~ns}$ & $0.31^{\mathrm{a}}$ & $0.23 \mathrm{~ns}$ & $0.23 \mathrm{~ns}$ & & & \\
\hline Colour & $0.32^{\mathrm{a}}$ & $-0.16 \mathrm{~ns}$ & $-0.69^{a}$ & $-0.69^{a}$ & $-0.71^{\mathrm{a}}$ & $-0.79^{a}$ & $-0.63^{\mathrm{a}}$ & $-0.57^{\mathrm{a}}$ & & \\
\hline Turbidity & $-0.68^{\mathrm{a}}$ & $0.79^{\mathrm{a}}$ & $-0.65^{\mathrm{a}}$ & $-0.64^{\mathrm{a}}$ & $-0.59^{a}$ & $-0.66^{\mathrm{a}}$ & $-0.70^{\mathrm{a}}$ & $0.30^{\mathrm{a}}$ & $0.41^{\mathrm{a}}$ & \\
\hline Total Fe & $-0.27 \mathrm{~ns}$ & $0.55^{\mathrm{a}}$ & $-0.85^{\mathrm{a}}$ & $-0.85^{\mathrm{a}}$ & $-0.23 \mathrm{~ns}$ & $-0.38^{\mathrm{a}}$ & $-0.60^{\mathrm{a}}$ & $0.09 \mathrm{~ns}$ & $0.59^{a}$ & $0.70^{\mathrm{a}}$ \\
\hline
\end{tabular}

Numbers in bold are statistically significant P-value $<0.05$.

a $\mathrm{EC}$, electrical conductivity; $\mathrm{NO}_{3}-\mathrm{N}$, nitrate; $\mathrm{NO}_{3}-$, nitrate; $\mathrm{NO}_{2}-\mathrm{N}$, nitrite; $\mathrm{NaNO}_{2}$, sodium nitrite; $\mathrm{NO}_{2}-$, sodium superoxide; DQO; Colour; Turbidity. 


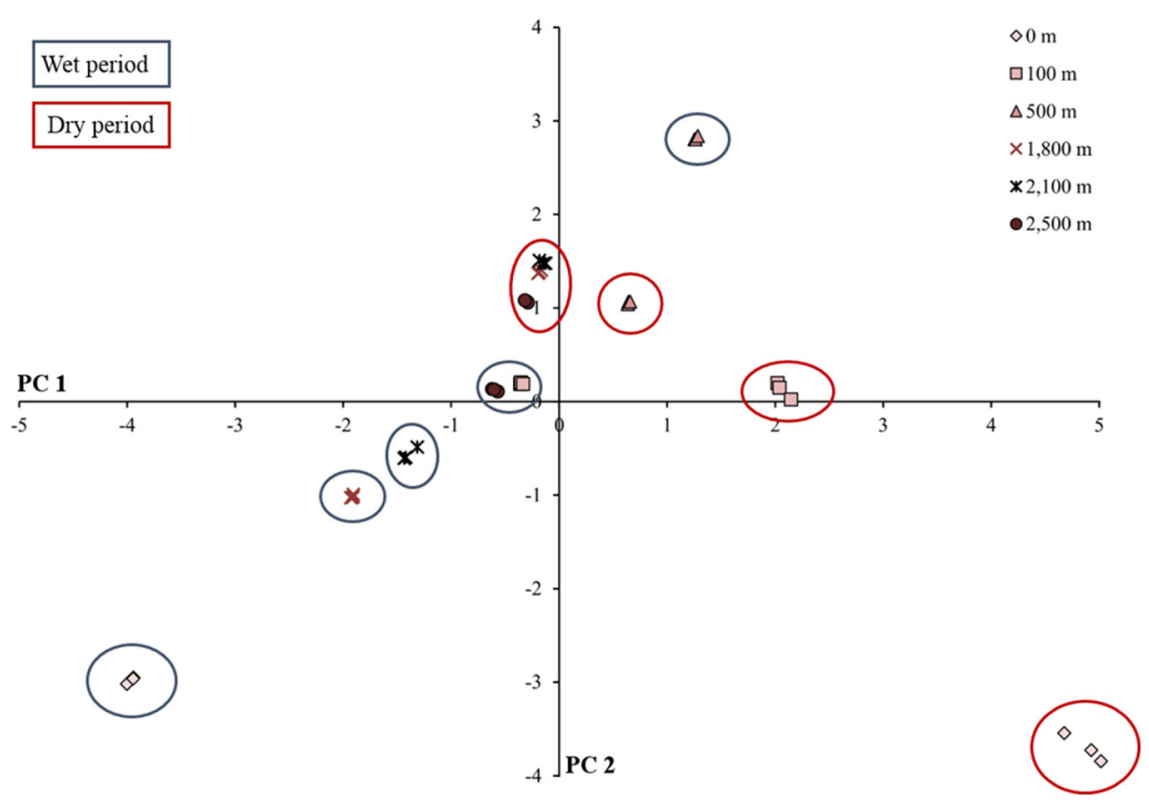

Fig. 7. Plot of the principal components analisys (PCA).

\section{Discussion}

The process linkages between catchment hydrology and streamwater chemistry requires chemical measurements on the time scale of hydrologic response in small catchments, and that time scale is on the order of minutes or hours (Kirchner et al., 2004). However, this research suggested that seasonality and urban or agricultural land uses had significant impacts on water quality in the study area. Our study reveals significant differences between land use and water quality and its temporal effect. Urban areas are located at the most upper headwater part of the catchment, whilst agricultural lands are random located along the river margins in the catchment with some patches of remnant riparian forests. Many different studies have shown that agricultural land uses at catchment scale is a primary predictor for water quality compounds (Smart et al., 1998; Ferrier et al., 2001; Ahearn et al., 2005; Kirchhoff et al., 2017). For example, Intensive agricultural activities together with population growth generate a potential source of contaminants from fertilizers, sewage disposal, and landfill, which often influence the hydrological system and change the runoff and water quality (Narany et al., 2017). Rodrigo-Comino et al. (2016) demonstrates that intensive agricultural uses generate soil erosion peak of sediment discharge, thus altering runoff water quality. In addition, Osborne and Wiley (1988) and Sliva and Williams (2001) observed high concentrations of chemical parameters in the streams of urbanized

Table 5

Principal components loadings.

\begin{tabular}{lll}
\hline & COMP1 & COMP2 \\
\hline pH & 0,314 & $-0,271$ \\
EC & 0,162 & $-\mathbf{0 , 3 1 7}$ \\
NO3-N & 0,275 & $\mathbf{0 , 3 6 5}$ \\
NO3- & 0,266 & $\mathbf{0 , 3 6 9}$ \\
NO2-N & $\mathbf{0 , 3 8 0}$ & $-0,309$ \\
NaNO2 & $\mathbf{0 , 3 4 6}$ & $-\mathbf{0 , 3 3 4}$ \\
NO2- & $\mathbf{0 , 3 4 8}$ & $\mathbf{0 , 3 3 1}$ \\
DQO & 0,146 & $\mathbf{0 , 1 6 2}$ \\
Colour & $\mathbf{- 0 , 3 2 8}$ & $-0,240$ \\
Turbidity & $\mathbf{- 0 , 3 1 3}$ & $-0,251$ \\
Total Fe & $\mathbf{- 0 , 3 3 7}$ & $-0,306$
\end{tabular}

*EC, electrical conductivity; $\mathrm{NO}_{3}-\mathrm{N}$, nitrate; $\mathrm{NO}_{3}-$, nitrate; $\mathrm{NO}_{2}-\mathrm{N}$, nitrite; $\mathrm{NaNO}_{2}$, sodium nitrite; $\mathrm{NO}_{2-}$, sodium superoxide; $\mathrm{DQO}$; Colour; Turbidity.

Higher and lower values are presented in bold. areas. This study indicates that the measured water quality parameters varied among the different sampling points from the headwater sampling point $(0 \mathrm{~m})$ to the last downstream sampling point $(2500 \mathrm{~m})$.

The urban area -located closed to the headwater $0 \mathrm{~m}$ above sea level sampling point- clearly influenced the higher values of $\mathrm{EC}, \mathrm{NaNO}_{2}, \mathrm{NO}_{2}$ and $\mathrm{NO}_{2}-\mathrm{N}$ concentrations. However, a downstream dilution effect caused a downstream decrease of $\mathrm{EC}, \mathrm{NaNO}_{2}, \mathrm{NO}_{2}$ and $\mathrm{NO}_{2}-\mathrm{N}$ concentrations probably promoted by the increase of effluent discharge and the buffer capacity of remnants riparian forests. As Keesstra et al. (2012) exposed, the riparian zone of the river channels has a significant effect on water and sediment transport in headwater catchments since high roughness in natural rivers due to vegetation and geomorphological attributes may generate drag on flowing water. This drag will slow water discharge, which in turn influences the sediment, physical and chemical components dynamics of the flow (Keesstra et al., 2012). This is also in accordance with Gao (2008) who showed that the riparian vegetation in headwater catchments play an important role in the resulting water and sediment dynamics of rivers further downstream.

Undisturbed catchments are characterized by very low in-stream ionic concentrations and by $\mathrm{EC}<10 \mu \mathrm{Scm}^{-1}$ that are negatively correlated to stream discharge (Markewitz et al., 2006). Moreover, the EC of stream water observed in agricultural areas cultivated by sugar cane normally reaches values close to $55.9-58.8 \mu \mathrm{Scm}^{-1}$ (Hunke et al., 2014). This finding is characteristic of regions with groundwater contributions from weathered in the Brazilian shield under baseflow conditions (Markewitz et al., 2006). Our results are in accordance with this trend, denoting a great influence of the agricultural land use and baseflow conditions.

Effluent discharges are an important factor controlling water quality parameters and an important relationship is illustrated between discharge and the distance effect on water quality parameters. Furthermore, at the downstream sampling points (i.e., 1800 and $2500 \mathrm{~m}$ sampling points), an increase of the concentration of colour, COD, turbidity and suspended solids was observed related with agricultural ditches triggering the coupling of agricultural hillslopes and stream (Slattery et al., 2002).

These trends were also influenced by the strong tropical seasonality due to results showed significant temporal differences combined with the land uses. This is accordance with Rangel-Peraza et al. (2009), who showed that water quality parameters have seasonal responses in large Tropical reservoirs. In this way, $\mathrm{pH}$ and EC illustrated contrasted 
dynamics along the main stream during both rainy and dry season (see Section 3.2). On the one hand, the urban reach (which comprises sampling points $0 \mathrm{~m}, 100 \mathrm{~m}$ and $500 \mathrm{~m}$ ) showed an inverse behaviour for both variables at each season. Thus, with higher discharge values in the rainy season, $\mathrm{pH}$ and $\mathrm{EC}$ were higher probably because sewers can discharge via combined sewer overflows (CSOs) an input of water flow to the main stream channel during intense rainstorms. In the dry season, $\mathrm{pH}$ and EC showed lower values than during the rainy season due to the absence of rainstorms despite the discharge values were lower and then avoided the dilution effect. On the other hand, during the rainy season in the agricultural reach (which comprises the $1800 \mathrm{~m}$ sampling point and further downstream) pH and EC were lower than in the dry season because agricultural effluents and buffering capacity of riparian remnant forests caused a dilution effect. Finally, these marked differences caused by seasonality and land use effects on water quality have been illustrated by the PC analysis, which clearly clustered all the analysed samples according to seasonality and sampling point distance.

\section{Conclusions}

Our results clearly showed temporal differences in the linkage between land use and water quality, thus highlighting the importance of multiple spatial and temporal scales for understanding the impacts of human activities on catchment ecosystem services. Based on the statistical analyses used, the physic-chemical parameters used in this study were significantly influenced by seasonality and land uses. It is obvious from the study that the riparian zone of the river channels has an important effect on water quality and that intensive agricultural used and urban area may deteriorate water quality in tropical catchments. Thus and under the catchment management point of view, riparian vegetation should be promoted in stream channels and intensive agricultural uses in adjacent areas should be avoided in order to not alter water quality. The comprehension of the relationship between land use and water quality may improve the science and land-use policies, enabling a better management of future impacts of global change such as land use and climate changes.

\section{Acknowledgements}

Cláudio Angeli Sansígolo, Renato Farias do Valle Junior, Vera Lúcia Abdalla are greatly appreciated for organizing four field surveys to obtain stream water quality data, as well as for their following work in data analysis and the identification of the samples.

\section{References}

Ahearn, D.S., Sheibley, R.S., Dahlgren, R.A., Anderson, M., Jonson, J., Tate, K.W., 2005. Land use and land cover influence on water quality in the last free-flowing river draining the western Sierra Nevada, California. J. Hydrol. 313, 234-247.

Allan, J.D., 2004. Landscapes and riverscapes: the influence of land use on stream ecosystems. Annu. Rev. Ecol. Syst. 35, 257-284.

Baker, A., 2003. Land use and water quality. Hydrol. Process. 17 (12), 2499-2501.

Carter, J., Owens, P.N., Walling, D.E., Leeks, G.J.L., 2003. Fingerprinting suspended sediment sources in a large urban river system. Sci. Total Environ. 314-316, 513-534.

Cerdà, A., Lucas-Borja, M.E., Úbeda, X., Martínez-Murillo, J.F., Keesstra, S., 2017. Pinus halepensis M. versus Quercus ilex subsp. Rotundifolia L. runoff and soil erosion at pedon scale under natural rainfall in Eastern Spain three decades after a forest fire. For. Ecol. Manag. 400, 447-456

Connolly, N.M., Pearson, R.G., Loong, D., Maughan, M., Brodie, J., 2015. Water quality variation along streams with similar agricultural development but contrasting riparian vegetation. Agric. Ecosyst. Environ. 213, 11-20.

Ferrier, R.C., Edwards, A.C., Hirst, D., Littlewood, I.G., Watts, C.D., Morris, R., 2001. Water quality of Scottish rivers: spatial and temporal trends. Sci. Total Environ. 265, 327-342.

Gao, P., 2008. Understanding watershed suspended sediment transport. Prog. Phys. Geogr. 32, 243-263.
Grip, H., Fritsch, J.M., Bruijnzeel, L.A., 2004. In: Bonell, M., Bruijnzeel, L.A. (Eds.), Soil and Water Impacts During Forest Conversion and Stabilization to New Land Use. Forests, Water, and People in the Humid Tropics: Past, Present and Future Hydrological Research for Integrated Land and Water Management. Cambridge University Press, pp. 561-589.

Hartemink, A.E., Veldkamp, A., Bai, Z., 2008. Land cover change and soil fertility decline in tropical regions. Turk. J. Agric. For. 32, 195-213.

Hunke, P., Mueller, E.N., Schroeder, B., Zeilhofer, P., 2014. The Brazilian Cerrado: assessment of water and soil degradation in catchments under intensive agricultural use. Ecohydrology. https://doi.org/10.1002/eco.1573.

Keesstra, S.D., 2007. Impact of natural reforestation on floodplain sedimentation in the Dragonja basin, SW Slovenia. Earth Surf. Process. Landf. 32, 49-65.

Keesstra, S.D., Kondrlova, E., Czajka, A., Seeger, M., Maroulis, J., 2012. Assessing riparian zone impacts on water and sediment movement: a new approach. Neth. J. Geosci. 91 (1-2), 245-255.

Keesstra, S.D., Temme, A.J.A.M., Schoorl, J.M., Visser, S.M., 2014. Evaluating the hydrological component of the new catchment-scale sediment delivery model LAPSUS-D. Geomorphology 212, 97-107.

Kirchhoff, M., Rodrigo Comino, J., Seeger, M., Ries, J.B., 2017. Soil erosion in sloping vineyards under conventional and organic land use managements (Saar-Mosel valley, Germany). Cuadernos de Investigación Geográfica 43, 119-140.

Kirchner, J.W., Feng, X., Neal, C., Robson, A.J., 2004. The fine structure of water-quality dynamics: the (high-frequency) wave of the future. Hydrol. Process. 18, 1353-1359.

Lee, S., Hwang, S., Lee, S., Hwang, H., Sung, H., 2009. Landscape ecological approach to the relationships of land use patterns in watersheds to water quality characteristics. Landsc. Urban Plan. 92, 80-89.

Markewitz, D., Resende, J.C.F., Parron, L., Bustamante, M., Klink, C.A., Figuereido, R.O., Davidson, E.A., 2006. Dissolved rainfall inputs and streamwater outputs in an undisturbed watershed on highly weathered soils in the Brazilian cerrado. Hydrol. Process. 20, 2615-2639.

Masselink, R.J., Heckmann, T., Temme, A.J., Anders, N.S., Gooren, H., Keesstra, S.D., 2017. A network theory approach for a better understanding of overland flow connectivity. Hydrol. Process. 31 (1), 207-220.

Masselink, R., Temme, A.J.A.M., Giménez, R., Casalí, J., Keesstra, S.D., 2017. Assessing hillslope-channel connectivity in an agricultural catchment using rare-earth oxide tracers and random forests models. Cuadernos de Investigación Geográfica 43, 19-39.

Narany, T.S., Aris, A.Z., Sefie, A., Keesstra, S., 2017. Detecting and predicting the impact of land use changes on groundwater quality, a case study in Northern Kelantan, Malaysia. Sci. Total Environ. 599, 844-853.

Osborne, L.L., Wiley, M.J., 1988. Empirical relationships between land-use cover and stream water-quality in an agricultural watershed. J. Environ. Manag. 26, 9-27.

Parsons, A.J., Bracken, L., Poeppl, R.E., Wainwright, J., Keesstra, S.D., 2015. Introduction to special issue on connectivity in water and sediment dynamics. Earth Surf. Process. Landf. 40 (9), 1275-1277.

Pérez Hernández, D., López, J.L., 1998. Alguno aspectos relevantes de la hidrología del Río Orinoco. In: López Sánchez, J.L., Saavedra Cuadra, I.I., Dubois Martínez, M. (Eds.), El Río Orinoco. Aprovechamiento Sustentable. Mémorias de las primeras jornadas venezolanas de investigación sobre el Río Orinoco. Instituto de Mecánica de Fluidos, Facultad de Ingeniería, Universidad Central de Venezuela, Caracas, pp. 138-154 16 e 20 noviembre de 1998.

Rangel-Peraza, J.G., De Anda, J., González-Farias, F., Erickson, D., 2009. Statistical assessment of water quality seasonality in large tropical reservoirs. Lakes Reserv. Res. Manag. 14, 315-323.

Ribeiro Rodrigues, R., Lúcia Ramos Bononi, V., 2008. Diretrizes para a conservação e restauração da biodiversidade no Estado de São Paulo, São Paulo. Secretaría del Medio Ambiente/Instituto de Botánica.

Rodgers, J.L., Nicewander, W.A., 1988. Thirteen ways to look at the correlation coefficient. Am. Stat. 42 (1), 59-66.

Rodrigo-Comino, J.R., Quiquerez, A., Follain, S., Raclot, D., Le Bissonnais, Y., Casalí, J., Pereira, P., 2016. Soil erosion in sloping vineyards assessed by using botanical indicators and sediment collectors in the Ruwer-Mosel valley. Agric. Ecosyst. Environ. 233, $158-170$.

Rodrigues, V.A., Carvalho, W.A., 2009. Morfometria da microbacia do Córrego Água Limpa. 39. Revista do Instituto Floréstal e IF Série Registros, São Paulo, pp. 15-24.

Rodrigues, V.A., Madruga PR de, A., García Morote, F.A., Lucas-Borja, M.E., 2015. Conflicto en las zonas de conservación de la microcuenca de Córrego Água Limpia (São Paulo Brasil). Cuadernos de La Sociedad Española de Ciencias Forestales 41, 1-10.

Singh, P., Haritashya, U.K., Kumar, N., 2004. Seasonal changes in meltwater storage and drainage characteristics of the Dokriani Glacier, Garhwal Himalayas (India). Hydrol. Res. 35 (1), 15-29.

Slattery, M.C., Gares, P.A., Phillips, J.D., 2002. Slope-channel linkage and sediment delivery on North Carolina coastal plain cropland. Earth Surf. Process. Landf. 27:1377-1387. https://doi.org/10.1002/esp.436.

Sliva, L., Williams, D.D., 2001. Buffer zone versus whole catchment approaches to studying land use impact on river water quality. Water Res. 35, 3462-3472.

Smart, R.P., Soulsby, C., Neal, C., Wade, A., Cresser, M.S., Billett, M.F., Langan, S.J., Edwards, A.C., Jarvie, H.P., Owen, R., 1998. Factors regulating the spatial and temporal distribution of solute concentrations in a major river system in NE Scotland. Sci. Total Environ. 221, 93-110.

Van Eck, C.M., Nunes, J.P., Vieira, D., Keesstra, S., Keizer, J.J., 2016. Physically-based modelling of the post-fire runoff response of a forest catchment in Central Portugal: using field versus remote sensing based estimates of vegetation recovery. Land Degrad. Dev. 27 (5), 1535-1544. 